\title{
A Communities of Practice Approach to Field Experiences in Teacher Education
}

\author{
Connor Kirwan Warner \\ University of Missouri-Kansas City
}

\section{Heidi L. Hallman}

University of Kansas

\begin{abstract}
This article argues that prospective teachers who have the most productive experiences within pre-student teaching field experiences are those whose field sites allow them to become members of communities of practice, the conditions of which, according to Wenger (1998) include joint enterprise, mutual engagement, and shared repertoire. Employing interviews and content analysis of documents, the researchers explored the experiences of a cohort of teacher candidates in a pre-student teaching practicum to better understand elements of field experience that might influence identity development. We highlight the cases of two prospective teachers as illustrative and contrasting experiences of the cohort as a whole. We conclude by offering recommendations for how teacher education programs might assist prospective teachers with negotiating for conditions within field sites that allow for productive participation and growth.
\end{abstract}

Keywords: Teacher education, field experience. community of practice. practicum

Connor Kirwan Warner, Ph.D., is an Assistant Professor of Teacher Education \& Curriculum Studies at the University of Missouri-Kansas City. A former high school English and social studies teacher, his primary research agenda centers on the interplay of teacher education policy, curriculum, and assessment, while his secondary research interests include issues of curriculum and representation in English and social science education.

E-mail: warnerck@umkc.edu

Heidi L. Hallman, Ph.D., is an Associate Professor of Curriculum \& Teaching at the University of Kansas. A former high school English teacher, her research interests include studying "at risk" students' literacy learning as well as how prospective English teachers are prepared to teach in diverse school contexts.

E-mail:hhallman@ku.edu 
Fostering possibilities for teacher candidates to succeed and learn from successes within field experiences promotes growth and understanding of the teaching act. In this article, we complement existing literature on field experiences in teacher education by bringing Wenger's (1998) communities of practice to bear. We argue that teacher candidates who have the most productive pre-student teaching field experiences are those whose sites allow them to become members of communities of practice, the conditions of which, according to Wenger (1998) include joint enterprise, mutual engagement, and shared repertoire. Employing phenomenological interviews and content analysis of documents, we explored the experiences of a cohort of teacher candidates in a pre-student teaching field experience to better understand elements of field experience that influence teacher identity development. We conclude by recommending ways that teacher education programs might assist teacher candidates with negotiating for conditions within field sites to allow for productive participation and growth.

\section{Conceptual Framework and Literature Review}

Identity, as a component of teachers' development, has been theorized as fluid and complex, as well as inherently 'social' (Alsup, 2006). Holland, Lachicotte, Skinner, and Cain (1998) discuss the premise that "identities, the imaginings of self in worlds of action, [are]...lived in and through activity and so must be conceptualized as they develop in social practice" (p. 5). Alongside other scholars who study teacher identity (e.g., Alsup, 2006; Zembylas, 2008), this article understands that teachers are produced as "particular types of professionals" (Zembylas, 2008, p. 124, italics in the original), and take up their identity as teachers through a project of continuous "becoming" (Gomez et al., 2007). Furthermore, teachers mediate their stories of self with the cultural and institutional expectations of what it means to be teachers. Identity is always in relationship with the contexts in which it is fostered, and teacher identity has been considered central to teacher development (Alsup, 2006; Britzman, 1991). We wish to further expand upon how teacher identity exists in relation to the complex sociocultural contexts that shape both the work and the people doing that work (Lavadenz \& Hollins, 2015). In referencing these sociocultural contexts, Gomez et al. (2007) state, "in such communities of prospective teachers...zones of contact in which the ideological positions that preservice teachers bring to teacher education are made visible and prominent" (p. 2133).

To explore the dynamics within field experiences, we look to Wenger's (1998) communities of practice. We see the community of practice framework as explicitly tying teacher identity to the sociocultural contexts in which identity is shaped. Communities of practice are "groups of people informally bound together by shared expertise and passion for a joint enterprise" (Wenger \& Snyder, 2000, p. 139). Within such groups, "each participant in a community of practice finds a unique place and gains a unique identity" (Wenger, 1998, p. 76). Scholars who have explored how communities of practice can be harnessed in the context of teaching have illustrated such communities as professional development for veteran teachers (Hollins, McIntyre, DeBose, Hollins, \& Towner, 2004; Lotter, Yow, \& Peters, 2014), as support for retention of novice teachers (Cuddapah \& Clayton, 2011), as bridges between disciplines (Spalding \& Wilson, 2006), as means for connecting research and practice (Friedrichsen, Munford, \& Orgill, 2006; Wesley, 2003), and as frames for understanding educational leadership (Margolin, 2012). In teacher education, Kaschak and Letwinsky (2015) discuss how the emergence of a community of practice within their methods course, a result of a collaborative service-learning project, encouraged prospective teacher confidence and self-efficacy. Likewise, Daniel, Auhl, and Hastings (2013) found that 
development of a community of practice for teacher candidates in their first professional semester helped participants develop the confidence to engage in productive critique. Collectively, these studies generally concur that there are positive impacts of both deliberate and serendipitous communities of practice within prospective teacher preparation coursework. Yet, less has been written about the function of communities of practice within teacher education field experiences.

Friedrichsen et al. (2006) has argued that field experiences serve as the intersection of two communities of practice, represented by the mentor teacher/pre-service teacher dyad. The success of the field experience, according to Friedrichsen et al. (2006) depends upon the ability of the prospective teacher to broker, or make connections (Wenger, 1998), across the two communities. Like Friedrichsen et al. (2006), our work sees the concept of communities of practice as especially pertinent to understanding prospective teachers' work in field experiences. First, though, we begin by defining the characteristics of communities of practice, according to Wenger (1998). These characteristics include: joint enterprise, mutual engagement, and shared repertoire.

\section{Joint Enterprise}

In order for a community of practice to exist, the people in a community must work together to develop a "complex, collectively negotiated response to what they understand to be their situation" (Wenger, 1998, p. 78). The key element in a joint enterprise is not that all participants agree fully on all aspects of the practice, but that they work together to negotiate ways in which their individual understandings can coexist and coordinate in service of common goals.

\section{Mutual Engagement}

The negotiation of the joint enterprise can only happen if participants are mutually engaged in practice. Mutual engagement refers to the development of "interpersonal relationships" (Wenger, 1998 , p. 76) within a particular practice. At its root, mutual engagement means "[b]eing included in what matters." (p. 74). Not every member of a community of practice must be engaged in the same way, but for a community of practice to exist, all members must feel that they hold a stake within the joint enterprise of the practice, and must feel a sense of agency in shaping the shared repertoire of that practice.

\section{Shared Repertoire}

The shared repertoire of a community of practice refers to the observable actions of a practice, as well as the concrete artifacts used during those actions. Examples include: "routines, words, tools, ways of doing things, stories, gestures, symbols, genres, actions or concepts that the community has produced or adopted" (Wenger, 1998, p. 83). This shared repertoire helps participants to concretely define their joint enterprise and to facilitate their mutual engagement in that joint enterprise. 


\section{Field Experiences in Teacher Education}

The primary entry points of teacher candidates into the community of practice of professional teaching are the experiences embedded within their teacher preparation programs that place them within pK-12 schools. Commonly referred to as practica or practicum experiences in international teacher education literature and as field experiences or clinical experiences in the United States, this component of teacher education is consistently rated by teacher candidates as among the most valuable parts of their preparation (White \& Forgasz, 2016). This is despite the fact that "Often, the clinical side of teacher education has been fairly haphazard, depending on the idiosyncrasies of loosely selected placements with little guidance about what happens in them and little connection to university work" (Darling-Hammond, 2006, p. 308). Given this concurrent value and variance, we undertook this study to develop a deeper understanding of conditions that might lead to more productive field experiences.

We situate our inquiry as examining a particular phase of field experience, which we refer to as an intermediate field experience (See Figure 1 below). These intermediate field experiences serve as a bridges between theory and practice, and are often the contexts in which new teachers begin developing personal teaching competence (Smith \& Lev-Ari, 2005). Field experiences occurring prior to student teaching, referred to commonly as early field experiences, are generally underresearched (Capraro, Capraro, \& Helfeldt, 2010; Heafner \& Plaisance, 2012; Huling, 1998). While intermediate field experiences are sometimes categorized as 'early' field experiences because they occur before the student teaching semester, we see them as qualitatively different from the passive observation that characterizes many teacher candidates' initial entry into pK-12 settings (Heafner \& Plaisance, 2012), and, like Capraro et al. (2010), argue that more research is needed concerning the unique role that such experiences have in teacher education programs. The program on which this paper is based included a series of field experiences that increased in time and candidate participation over the four semesters before the culminating semester, the student teaching semester.

\begin{tabular}{|c|c|c|}
\hline Early Field Experiences & Intermediate Field Experiences & Student Teaching/Internship \\
\hline $\begin{array}{l}\text { Occurring near the } \\
\text { beginning of, or even } \\
\text { before formal admission to, } \\
\text { a teacher preparation } \\
\text { program }\end{array}$ & $\begin{array}{l}\text { Occurring in the middle of } \\
\text { a teacher preparation } \\
\text { program } \\
\text { Intended to help candidates } \\
\text { develop particular } \\
\text { competencies, bridge } \\
\text { theory to practice, and } \\
\text { transition into professional } \\
\text { teaching practice } \\
\text { - Widely varying in character }\end{array}$ & $\begin{array}{l}\text { - Occurring in the final year } \\
\text { or semester of a teacher } \\
\text { education program } \\
\text { - Intended to provide } \\
\text { candidates with the } \\
\text { opportunity to achieve and } \\
\text { demonstrate competence in } \\
\text { all aspects of the teaching } \\
\text { role } \\
\text { Characterized by full-time } \\
\text { placement in a school with } \\
\text { eventual assumption of the } \\
\text { majority of duties of a full- } \\
\text { time teacher }\end{array}$ \\
\hline
\end{tabular}

Figure 1. Levels of field experience/practica 
Given our interest teacher candidate identity development and how it might be made more visible to candidates through intermediate field experiences, this paper asks the following questions:

1. How do teacher candidates negotiate and make visible their teacher identity through participation in an intermediate field experience? How can a community of practice framework assist in understanding this negotiation?

2. How might teacher education programs foster communities of practice within intermediate field experiences?

\section{Methods}

We have described this inquiry as phenomenological in the sense articulated by Seidman (2013), as we are primarily interested in the "experiences of participants and the meaning they make of that experience" (p. 16). We wanted to know how our participants understood and negotiated the tensions inherent in their field experience contexts, and we wanted "to come as close as possible to understanding the true 'is' of our participants' experience from their subjective point of view" (p. 17). This recognition of the subjective, yet still formative and powerful, nature of lived experience shaped our data collection, analysis, and reporting methods, leading us, as much as possible, to foreground the voices and interpretations of our participants themselves.

\section{Context and Participants}

The site of our inquiry is an intermediate field experience situated in the fall of teacher candidates' final year of teacher education coursework. This experience occurs before candidates' student teaching semester, yet comes after initial experiences that could be characterized as 'observations' of classrooms (Hollins, 2015). The larger study on which this paper is based focused on the experiences of 14 English teacher candidates from a large university in the Midwest United States. Participant selection for this study was based upon the concept of purposeful sampling (Lincoln \& Guba, 1985), and the intent of the study was to gain in-depth understanding of the holistic experiences of an entire cohort of prospective English teachers.

\section{Data Collection}

The primary data collection methods included group interviews and in-depth individual interviews, insights from which were then triangulated through the analysis of documents produced within field experience contexts (Lincoln \& Guba, 1985; Marshall \& Rossman, 2006; Merriam, 2009; Patton, 2002; Seidman, 2013). Participants were interviewed at several points. These interviews were semi-structured, with researchers asking open-ended questions to allow the participants to emphasize aspects of experience that they found essential for making meaning (Seidman, 2013). Initially, participants were divided into small groups based upon the location and grade level of their field experience. After group interviews, participants were also interviewed individually. Emerging themes from interviews were triangulated with data drawn from artifacts (e.g., Blackboard discussion posts and reflection papers).

Connor served as the university supervisor of the teacher candidates who participated in the study and Heidi was an instructor for the methods class in English teaching within the teacher education program. During the time of data collection, the researcher responsible for grading the 
participants was not the researcher collecting data; this minimized the tendency that participants might feel compelled to take part in the study.

\section{Data Analysis}

As data was collected, it was inductively analyzed and thematically coded using constant comparison (Strauss \& Corbin, 1994). This process generated a list of codes that were organized into categories, and, eventually, into emergent themes (Lincoln \& Guba, 1985; Merriam, 2009). These emergent themes were then deductively analyzed using Wenger's (1998) communities of practice as a lens (Patton, 2002). Specifically, we compared our emergent themes to the three definitive elements of communities of practice detailed previously-joint enterprise, mutual engagement, and shared repertoire-finding that the majority of our themes fit easily into at least one of these three categories.

Inductive and deductive coding helped the researchers see across cases, and though the experiences of all participants contributed to and corroborated our understanding of the ability of communities of practice to influence growth and identity development, we choose, in this article, to highlight the cases (Stake, 1995) of two participants, referred to as Tom Martin and Andrea Adams. The richness of their stories, as told to us, as well as the fact that their cases presented contrasting experiences, position these two participants as "telling" cases (Ellen, 1984), highlighting particular issues and themes that recurred across the broad spectrum of participants. The experiences of Tom and Andrea can be viewed as existing on opposing sides of a continuum of involvement, ranging from full immersion in a robust community of practice to outside observation of a setting without establishing any real belonging (see Figure 1 below). The experiences of other participants in the larger study would be positioned in between these two cases.

Full Immersion in (CoP)

Outside Observation

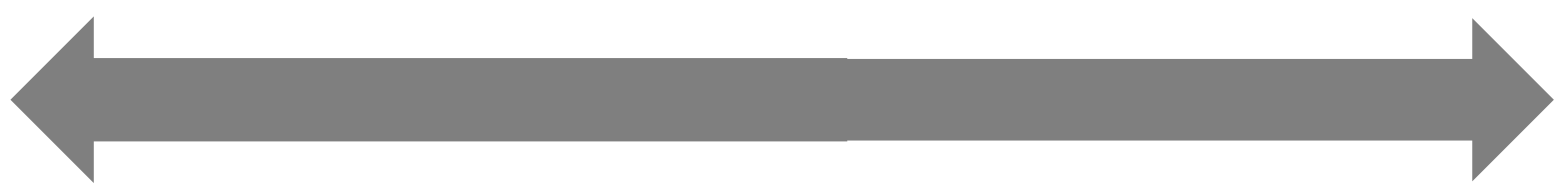

Figure 2. Continuum of participation in community of practice $(\mathrm{CoP})$

To aid in illustrating this argument, the three primary descriptors identified by Wenger (1998) as defining individual communities of practice - joint enterprise, mutual engagement, and shared repertoire - are seen as deductive codes framing the two cases. They are used throughout the findings section to discuss Tom and Andrea's experiences. 


\section{Findings}

\section{Tom Martin}

Tom's experience working at North Middle School exemplifies what engaging in a productive community of practice for teaching and learning to teach looked like in the field experience. Tom was a white male who grew up in a suburban town on the outskirts of a Midwestern U.S. city. Tom's field experience took place in an eighth grade language arts classroom at a middle school, hereafter referred to as North Middle School, in the same small city that houses Midwest University. His cooperating teacher, a white female who we refer to as Ms. Faber, had been teaching at North for over a decade, and had previously supervised a number of teacher candidates in all three levels of field experience described in Figure 1. She was a confident teacher who served as the lead eighth grade language arts instructor at the middle school.

Tom experienced positive professional identity development and indicated a strong sense of satisfaction and personal growth as a result of his field experience. When asked at the end of his experience what he would have done differently if given the opportunity, he answered, "I love being there [so] much...if I could go back, I'd have prioritized everything else in my life to give my students more time." Tom and Ms. Faber were able to mutually engage in the joint enterprise of teaching eighth graders at North Middle School and as well as work on expanding Tom's professional knowledge and skills. Their engagement was built upon a fundamental mutual respect for each other's skills and knowledge. Tom described it this way:

[Ms. Faber]'s been teaching a while, you know, she's been at this, teaching for a long time, and her training was more than a decade ago, so I know some things that she doesn't. But we have a mutual respect, I think because I first respected her, and I showed excitement and gratitude for being in her classroom, and I think that first impression made a big difference. I mean, I showed up like this was a new job and I was getting on-the-job training, and I wasn't going to let myself be discouraged when I couldn't do things exactly my way. Teaching is a profession, and in every profession you have to work your way up and learn on the go.

Such mutual respect allowed Tom and Ms. Faber to construct Tom's learning experience throughout the semester in a manner congruent to both their understandings of how best to learn to teach. Tom explained: "I was teaching something of my own design the very first week. Ms. Faber said the best way to introduce you is to just have you do it, which is a philosophy that I personally agree with." Their complimentary understandings of the joint enterprise in which they were engaged helped Tom to mutually engage in professional practice. Tom described the first time that felt he had made a significant transition from student to teacher, noting,

I guess it was probably during my first mini-lesson on 6 traits. I didn't really want to teach that, but I wanted to teach, so I taught it. I was struggling a little with management, and I made a joke with a reference to a video game, and they laughed and got it and the students started to interact with me without her mediating. I had command and authority because they gave it to me. I think I was able to do that so early because I was able to develop a close relationship with my cooperating teacher, and she fosters a good relationship with her students.

Despite holding a different view on the value a particular element of the curriculum, Tom was still able to productively engage in the community of practice within that classroom.

Contributing to that community of practice was the shared repertoire of procedures and artifacts

Brock Education Journal, 26(2), 2017 
that Tom and Ms. Faber were able to construct. Lesson plans and curriculum documents are some of the most common artifacts in the practice of teaching, and, along with developing systems of classroom management, understanding lesson planning is often one of the most common concerns of the novice teacher. Ms. Faber's planning process, while hardly concrete, resonated with Tom. He noted the following:

I think the biggest way that I relate to my teacher is that she says all the time..."I don't have my curriculum planned out [because] I've been doing it for a long time," which is something I relate to. I want to have things I want to cover, but I don't want to have those planned to the day, and that goes along with her kind of organic storytelling type deal that she only has the next couple weeks planned out but still gets through everything she wants to cover. She'll be the first to tell you that her students do the best on the test of the eighth grade English teachers in the area. She says she's glad that I'm like that because some of her students in the past had a hard time.

Ms. Faber noted that some of the teacher candidates she had worked with in the past held a different understanding of the importance of concrete long-term planning than she did, and so struggled to grow within her classroom. Tom, on the other hand, who held similar beliefs to his cooperating teacher, thrived in that environment. Because of the community Tom and Ms. Faber were able to build, any negotiations resulted in significant learning as positive professional identity development for Tom.

\section{Andrea Adams}

Andrea's case exemplifies the tensions we observed for participants who were unable to engage in a productive community of practice for teaching and learning to teach within their intermediate field experiences. Andrea was a white female who grew up in a different suburban town on the outskirts of the same Midwestern U.S. city as Tom. Andrea's field experience took place in a high school, hereafter referred to as West High School, in the same district as North Middle School. Her cooperating teacher, who we refer to as Mr. Higgins, was a white male who had worked at West High for over 15 years and was the chair of the English department. Though he had supervised numerous teacher candidates in the past, at the time of the study it had been several years since he had hosted any in his classroom. He was a commanding and demanding teacher who believed above all else in the primacy of content knowledge and intellectual rigor.

Andrea's experience is representative of those participants whose field placements did not provide them the opportunity to enter communities of practice, and who, therefore, experienced negative or stagnant professional identity development and indicated dissatisfaction with their experiences. Andrea felt constrained in a variety of ways, as though she were an outsider to the very experience in which she was involved. She also expressed some concern about her future career, given the struggles she found in the classroom in which she was placed. She noted, "I realize that teaching is a very challenging career, consisting of a lot of extra time, energy, and work... I'm more concerned that the students won't want to at least meet me halfway."

Unfortunately, unlike Tom, Andrea never felt able to mutually engage with Mr. Higgins in the practice of teaching during her field experience. This was at least partially due to the very different understandings of the teaching enterprise held by Andrea and Mr. Higgins and their inability to negotiate those differences. When asked about her experience, Andrea said, "I feel intimidated by [Mr. Higgins] as a new teacher. I don't want to deviate from his lesson plans, his ways of doing things, even though he tells me I can. I feel like I have to do lectures because that's what he does, 
so obviously he thinks it's the best way to go." Even though Mr. Higgins indicated on his formal evaluations of Andrea that he was willing to let her experiment with different methods and pedagogies, she did not feel comfortable doing so.

The unequal power dynamic that existed between Andrea and Mr. Higgins seemed to play a considerable part in an inability to mutually engage. While Tom and Ms. Faber were able to develop a respectful relationship in which both were willing to learn from each other, despite the fact that Ms. Faber was ultimately the authority in the classroom, Andrea and Mr. Higgins were unable to do so. This was likely at least partially due to Mr. Higgins' own status within West High School; Andrea noted that, "he's the department chair, in charge of hiring, so if I wanted to work here I need him on my side." The radically unbalanced dynamic meant that Andrea never felt that she was a legitimate participant in teaching practice while in the presence of Mr. Higgins. She noted that the only time she really felt like a teacher during her field experience was the day that Mr. Higgins was absent, and, though the district hired a substitute teacher, Andrea led the class. She described her feeling of strength and legitimacy, noting, "I was in control and I was the 'go to' person. When [Mr. Higgins] is in the room, no matter what, he's the 'go to."'

Due to their conflicting conceptions of the work of teaching and their inability to mutually engage in the field experience setting, Andrea and Mr. Higgins were unable to develop a shared repertoire of teaching practices and artifacts. One of the earliest manifestations of this lack of shared repertoire involved the instructional planning process. Unlike Tom, Andrea struggled to understand the lesson planning process of her cooperating teacher and did not feel able to engage in a mutual negotiation of a process that would work for her. From her perspective, Mr. Higgins simply,

doesn't plan a lot... [maybe because] he's been doing it for so long [that] he [just] knows what he wants to say or what he wants to do. [When I'm watching] It seems to me like it's just off the top of his head, but then he starts talking, and it seems so well-planned out...it's just hard for me to see the angles of things or...even the progression of the unit or the day...He does a great job of conveying [the material, but]...it's hard for me to sit in there and have a clear view of what's going on and what the goals are.

Her observations of Mr. Higgins contrasted sharply with her own construction of planning for instruction. She described herself as,

a planner, I plan everything out... Which doesn't always parallel with my teacher's style...it works for him, but it just doesn't feel right to me.

Unlike Tom and Ms. Faber, Andrea and Mr. Higgins were never successful in developing a shared repertoire of planning processes and tools. Lack of shared repertoire was also apparent in Andrea and Mr. Higgins' differing perspectives regarding teaching methods. For Andrea, a defining characteristic of good teaching was social interaction. She described her frustration with Mr. Higgins' class, noting:

I'd like to be doing discussion and there's none of that... [students] won't even raise their hands to answer...it's like, they've been conditioned to sit there and listen and be passive learners and do the work, and I think that there's a lot to be learned from discussion.... and if it were my class, I would really push for the kids to open up to each other and comfortable sharing their ideas. It's frustrating...

From Andrea's viewpoint, social interaction defined both the goal and method of teaching. Mr. Higgins, however, seemed to understand teaching more in terms of content than social interaction, and so his teaching methods reflected this understanding. In his final evaluation of Andrea, he recommended that Midwest University require "more content knowledge and less educational 
theory" of their prospective teachers. Andrea described Mr. Higgins as, very college-like. He does a lot of lecturing...He doesn't think there is anything wrong with a teacher talking "at" students if the teacher has valid knowledge to convey...My cooperating teaching has a lot to offer. He knows the material forward and backward...

Andrea could appreciate some value in this approach, and certainly admired her cooperating teacher's deep-seated knowledge. However, she still felt that the essence of the enterprise of teaching, in her estimation, was lacking. She explained,

It's good for students to be able to sit and listen, since this is what the expectation will be in college, but I think these students are missing out on a key component of educationdiscussion. The students are never given time to discuss their opinions, argue topics, or really even ask questions. The kids are like robots, and it's not an atmosphere I feel comfortable with. I'm a very open person, who likes conversation [and] active learning.

When Andrea attempted to implement such a mode of teaching, she "got shot down" because Mr. Higgins said he "didn't see it working." Their lack of a common construction of teaching left Andrea feeling like an outsider, disengaged with the classroom, and not able to do what she felt she needed to do in order to learn what she felt she needed to learn. As she put it, "I see other teachers teaching the same level and same content as he does, but they do all kinds of different activities and cooperative learning, so I know it can be done. I just don't feel comfortable doing it here." In effect, the lack of a joint enterprise between Mr. Higgins and Andrea led directly to an inability to develop a shared repertoire of teaching methods, and, therefore, to a lack of mutual engagement in the work of teaching. The net result of all these tensions and disconnects was the inability to form a community of practice in which Andrea could productively learn to teach and develop her own professional identity.

In her methods class, Andrea was often quiet in discussions about her field experience. While others shared positive ways they were interacting with both the students in the classroom and their cooperating teacher, Andrea referred often to her experience with Mr. Higgins as "fine, but we have different philosophies." The idea of differing teaching philosophies is often a way for teacher candidates, like Andrea, to cope with an experience that does not lead to growth as a teacher and, in the next section, we explore how teacher education programs can go beyond a claim of a mismatch of teaching philosophies to help students like Andrea.

\section{Discussion}

We stress that participation in communities of practice resides on a continuum (see Figure 1). Because we place Tom's experience closer to full immersion in a community of practice and see Andrea's experience as closer to residing in an "outsider" position, we were led to consider the second question that frames our inquiry: How might teacher education programs help foster communities of practice within the pre-student teaching field experience?

We see this work as resting on assisting teacher candidates to develop what Wenger (1998) calls legitimate peripheral participation. Since field experiences are intended to allow teacher candidates to both practice teaching and to learn the practice of teaching, in order to learn within practice, participants "must be granted enough legitimacy to be treated as potential members" (Wenger, 1998, p. 101) and at least "an approximation of full participation that gives exposure to actual practice" (p. 100). Tom and Ms. Faber, though not necessarily deliberately, worked these elements out. Andrea and Mr. Higgins did not. Perhaps the most important finding was that whether or not the field experience resulted in positive growth and development for the teacher 
candidates involved seemed to be dependent not upon systems put in place by the teacher education program at Midwest University or even by the schools in which the teacher candidates were placed, but upon interconnected factors including personal theories of teaching and learning to teach, institutional and social power dynamics, and personality characteristics - none of which were deliberately analyzed, mediated, or deconstructed by the teacher education program. The following section is organized into a discussion of two explicit lessons that we believe teacher education programs can take away from the experiences of Tom and Andrea.

\section{Lesson 1: Develop a Shared Understanding of Teaching Itself}

First, the experiences of our participants indicate that incompatible understandings of the work of teaching and, as a corollary, what it means to be a teacher, can derail an intermediate field experience. Jackson (1986) noted that "despite the ubiquity of teaching as an activity, there is no uniformity of opinion about it...Teachers, it turns out, often disagree among themselves about teaching and what its demands are in the way of knowledge" (pp. 2-3). Such disagreement is salient, given that a wide variety of scholars have demonstrated the ways in which beliefs about and understandings of teaching shape the actual actions of teachers in practice (Darling-Hammond \& Bransford, 2005; Korthagen, 2004; White \& Forgasz, 2016). Most understandings of teaching include beliefs relating to curriculum content and planning, the value/effectiveness of particular pedagogies, the function and format of assessment (Hollins, 2015; Jackson, 1986; Joyce, Weil, \& Calhoun, 2014). Undergirding these understandings are differing theories about the way people learn and differing beliefs about the overarching goals of educational experiences and the nature of knowledge itself (Jackson, 1986; Labaree, 1997; Warner, 2016).

To address this issue, teacher education programs might emphasize the development of teaching as shared repertoire. According to Wenger (1998), developing repertoire, styles, and discourses means re-negotiating the meaning of various elements. It also means "producing or adopting tools, artifacts, representations; recording and retelling events; inventing new terms and redefining or abandoning old ones; telling and retelling stories; creating and breaking routines" (p. 95). Again, Andrea and Mr. Higgins simply did not have a shared repertoire of teaching strategies, procedures, experiences, or routines. Andrea chaffed at Mr. Higgins' emphasis on lecture and content and could not reconcile it with her own belief in personal relationships and social interaction. It was not that Andrea felt she did not have access to the artifacts of Mr. Higgins' practice. It was that, from her perspective, his practice did not seem to produce any artifacts other than students who mechanically took notes like "robots." As such, there was certainly no space for the two of them to work together to reify their practice into a shared repertoire of artifacts and routines.

On the other hand, Tom and Ms. Faber, by establishing a concrete schedule and negotiating a shared understanding of the meanings of observation, co-teaching, and teaching, and the routines and procedures that they would both employ to bring meaning to those activities, were able to share in a repertoire for both teaching and learning to teach. While cooperating teachers, as experts in their craft, may not think to make transparent the varied sophisticated decisions, routines, and artifacts that define their practice, a phenomenon that Darling-Hammond and Bransford (2005) called expert blind spots, teacher education programs could facilitate conversations between cooperating teachers and teacher candidates early in the experience to help underscore important elements of their practice such as lesson planning, classroom management, learning activities, teaching strategies, assessment development, and data use. These are the conversations and outcomes that Tom and Ms. Faber had, and that Andrea and Mr. Higgins did not. 


\section{Lesson 2: Develop a Shared Understanding of Learning Teaching}

Second, Tom and Andrea's experience highlight the essentiality that stakeholders in an intermediate field experience hold a shared understanding of how an individual learns teaching. If a cooperating teacher believes that a teacher candidate is going to learn teaching by observing and replicating his or her behavior, and the teacher candidate believes he or she is going to learn teaching through joint inquiry into learners and learning environments, then both are likely to be stymied in their efforts and dissatisfied with the experience. As the institution tasked with recommending candidates for licensure, it is incumbent upon the teacher education program to develop a clear, coherent conceptualization of learning teaching, and to ensure that the cooperating teachers who partner with the program and the teacher candidates it sends out into the field share that common understanding.

Wenger (1998) argued that members of the community of practice must be constantly involved in understanding and tuning their enterprise. This means that members must be willing to learn and hold each other accountable to their enterprise as well as reconcile conflicting interpretations of what the enterprise is about. For this to happen, teacher education programs might emphasize with prospective teachers the importance of learning to teach in new ways. In contrast to how field experiences have been conceptualized-as spaces for teacher candidates to observe master teachers and attempt to replicate their behaviors in a process that Hollins (2015) referred to as "representation and approximation" (p. 18) - a reconceptualization would stress field experiences as sites for examining the benefits and drawbacks of particular classroom practices. In such a framework, teaching is viewed not as a set of competencies or an act driven by a singular theory (Smith \& Lev-Ari, 2005); as a result, each teaching context requires different theories in practice. In this way, learning to teach becomes an interpretive process (Hollins, 2015) dependent upon analysis of learners and contexts.

In order to foster Wenger's tenet of mutual engagement in the teaching act, cooperating teacher and prospective teacher must be invested in each other's competence and how such competence evolves over time. Mutual engagement, according to Wenger (1998) "involves not only our competence, but also the competence of others" (p. 76). Teacher education programs might pay particular attention to what Wenger viewed as evolving forms of mutual engagement, including "discovering how to engage, what helps and what hinders; developing mutual relationships; defining identities, establishing who is who, who is good at what, who knows what, who is easy or hard to get along with" (p. 95).

Referencing the case of Andrea Adams, we can see that mutual engagement appears fundamental to successful and fulfilling field experiences. Andrea summed up the lack of mutual engagement in her field experience, stating in the introduction to one of her reflection papers, "I have taught several lessons, but unfortunately, due to [a variety of factors], I cannot be involved in the lesson planning and teaching every day." Tom, on the other hand, described the specific ways in which he and his cooperating teacher worked out ways for them to mutually engage in the joint enterprise of teaching the students at North Middle School. Tom spent approximately one hour per day, five days per week at his field site, and Tom described the way he and his co-teacher divided that time in the following way:

On average, I'm...observing and talking to the teacher about strategies for three days of the week. One day is co-teaching... and one day is full on teaching...I'm preparing to start a large unit of my own design, something I feel really lucky to take part in. 
Andrea, on the other hand, because of limitations in her own course schedule and because of her cooperating teacher's administrative duties, was unable to be in the classroom every day, and, instead, came in for several hours at a time, a couple of days per week. Those days tended to change from week to week, depending upon the availability of her cooperating teacher to meet and plan with her, since he frequently needed to use his non-teaching time to attend to department chair business.

\section{Implementing the Lessons}

If teacher education programs are to truly learn from these lessons, most will need to make substantial changes to the ways in which intermediate field experiences are designed, introduced, and supported, which will require addressing challenges of logistics, buy-in, and resources. Programs' recasting of field experiences, especially intermediate experiences, as professional development for both teacher candidates and cooperating teachers would emphasize the centrality of communication and the importance of all parties involved looking at the relationship as a site for learning (McQuirter, Scott, Dortmans, Rath, Meeussen, \& Boin, 2015: Roland, 2010). FeimanNemser \& Buchmann (1987) concluded their study of factors necessary for student teaching to serve as meaningful teacher education by arguing the following:

Becoming a mentor involves making a transition from classroom teacher to teacher educator. Classroom teachers need time and commitment to develop the necessary understandings, skills, and orientations, and schools must broaden the scope of teachers' roles and rewards to include teacher education. (273)

We concur, but would add that university teacher preparation programs will need to provide the structure, expertise, and experience necessary to help classroom teachers develop competence as teacher educators.

One approach that might allow teacher education programs to establish field experiences as mutual professional development is structured dialogue (Hollins, 2006). Structured dialogue is a problem-solving approach to teacher professional development pioneered by Hollins (2006) to improve literacy instruction and student achievement in urban schools in Dayton, $\mathrm{OH}$. The teachers involved in Hollins' study engaged in weekly dialogues in which they (1) jointly identified problems of practice, (2) identified possible solutions, and (3) developed plans to implement those solutions. Over the three-year course of the study, Hollins found that the approach led to productive changes in teacher habits of mind and school culture, which in turn led to increased student achievement. Hollins (2006) argued that "structured dialogue can bring about a learning community in which teachers transform their schools' beliefs, values, and instructional practices" (p. 52). We posit that such a powerful intervention could be harnessed within intermediate field experiences as well in order to establish the communities of practice for which we have advocated in this article.

We recommend that teacher education programs consider requiring not just hours of observation and practice teaching, but also hours of structured dialogue as part of the intermediate field experience. In such an approach, candidates and cooperating teachers would schedule a significant time, at least an hour per week, in which to engage in structured dialogue about teaching practice. Both parties would bring problems of practice to the dialogue, and both would be responsible for generating solutions, and considering the means of implementing those solutions. In an ideal context, multiple teacher candidates and cooperating teachers in the same school or department would meet within this structured dialogue group to maximize the generative nature of dialogue. 


\section{Limitations}

We have chosen to highlight two distinct cases throughout this article; however, we realize that by contrasting these cases, there is risk in presenting one "successful" case and one "unsuccessful" case rather than fully illuminating the continuum of experience that we observed. Some teacher candidates may experience truly immersive intermediate field experiences that would place them even further left along the continuum than Tom, while others (unfortunately, in our view), may be forced to the right of Andrea on Figure 2, and positioned as outsiders looking in. Yet, by outlining how tenets of communities of practice are present in this particular setting, we hope that teacher educators can be more expert in understanding the range of prospective teachers' experiences in field experiences through a more nuanced lens.

We are also left to postulate how teacher education programs might design intermediate field experiences that allowed teacher candidates to move further left on the continuum, even closer to full immersion in robust communities of practice. It is possible that a tipping point exists where teacher candidates in pre-student teaching field experiences might be immersed too quickly in a community of practice, bypassing, or passing too quickly through legitimate peripheral participation and being thrust directly into full participation. Such an experience, where teacher candidates would be asked to practice teaching before they had learned teaching might be as detrimental to their emerging professional identities as experiences on the far right of the continuum. Next, we move to place our work in the broader context of reform in North American teacher education.

\section{Conclusion and Implications}

Adopting a communities of practice approach to pre-student teaching field experience in teacher education would take a degree of cooperation and partnership with teachers and PK-12 schools that has not traditionally existed, despite a significant base of scholarly literature indicating the positive outcomes of such partnerships (Bier et al., 2012; Kenny, 2012; Margolin, 2012; Stairs, 2010; Trent \& Lim, 2010). However, the call for such partnerships is growing louder. For example, in Canada, the Accord on Initial Teacher Education (2016), which provides guiding, but not binding, principles for teacher education, argues that

An effective initial teacher education program involves partnerships between the university and schools, interweaving theory, research, and practice and providing opportunities for teacher candidates to collaborate with teachers to develop effective teaching practices. (p. 3)

In the United States, the Council for the Accreditation of Educator Preparation (CAEP), the national accrediting body for teacher preparation, has placed substantive emphasis on partnerships between teacher preparation programs and PK-12 schools as one of its core standards for program evaluation (CAEP, 2015). Hollins (2015) argued that, in developing such partnerships, teacher preparation programs should look to develop field experiences that function as "guided practice within a professional community...a type of apprenticeship that is significantly different from traditional conceptualizations of student teaching" (p. x).

Many teacher educators (e.g., Cochran-Smith, 1995; Gay, 2003) have asserted that what is needed in teacher education programs is space and opportunity for teacher candidates to work in contexts that will broaden their belief systems and assist in constructing more sophisticated 
understandings of students as learners. As this article suggests, the intermediate field experience, an often ignored feature of teacher education programs, can be a potential site for undertaking such work. A communities of practice approach, in theoretically framing such field experiences, could offer a robust framing of the field experiences that are intended to serve as transition points into professional teaching practice. As the field of teacher education reiterates a commitment to prepare teachers to teach diverse groups of students, it is important that this move beyond rhetoric and into the spatial and temporal contexts in which we live. 


\section{References}

Alsup, J. (2006). Teacher identity discourses: Negotiating personal and professional spaces. Urbana, Illinois: National Council of Teachers of English.

Association of Canadian Deans of Education. (2016). Accord on initial teacher education.

Retrieved from http://www.csse-scee.ca/docs/acde/ACDE_Accord_on_Initial_Teacher_Education.pdf

Bier, M. L., Horn, I., Campbell, S. S., Kazemi, E., Hintz, A., Kelley-Petersen, M., \& Peck, C. (2012). Designs for simultaneous renewal in university-public school partnerships. Teacher Education Quarterly(Summer), 127-142.

Britzman, D. P. (1991). Practice makes practice: A critical study of learning to teach. Albany, NY: State University of New York Press.

Capraro, M. M., Capraro, R. M., \& Helfeldt, J. (2010). Do differing types of field experiences make a difference in teacher candidates' perceived level of competence? Teacher Education Quarterly(Winter), 131-155.

Cochran-Smith, M. (1995). Color blindness and basket making are not the answers: Confronting the dilemmas of race, culture, and language diversity in teacher education. American Educational Research Journal, 32, 493-522.

Council for the Accreditation of Educator Preparation (CAEP). (2015). Standard 2: Clinical partnerships and practice. Retrieved on December 13, 2015, from http://caepnet.org/standards/standards/standard2/

Cuddapah, J. L., \& Clayton, C. D. (2011). Using Wenger's communities of practice to explore a new teacher cohort. Journal of Teacher Education, 62(1), 62-75.

Daniel, G. R., Auhl, G., \& Hastings, W. (2013). Collaborative feedback and reflection for professional growth: Preparing first-year pre-service teachers for participation in the community of practice. Asia-Pacific Journal of Teacher Education, 41(2), 159-172.

Darling-Hammond, L. (2006). Constructing 21st-century teacher education. Journal of Teacher Education, 57(3), 300-314.

Darling-Hammond, L., \& Bransford, J. (2005). Preparing teachers for a changing world: What teachers should learn and be able to do. San Francisco: Jossey-Bass.

Ellen, R. F. (1984). Ethnographic research: A guide to general conduct. New York: Academic Press.

Feiman-Nemser, S., \& Buchmann, M. (1987). When is student teaching teacher education? Teaching and Teacher Education, 3(2), 255-273.

Friedrichsen, P. M., Munford, D., \& Orgill, M. (2006). Brokering at the boundary: A prospective science teacher engages students in inquiry. Science Education, 90(3), 522-543.

Gay, G. (Ed.) (2003). Becoming multicultural educators: Personal journeys toward professional agency. San Francisco: Jossey-Bass.

Gomez, M.L., Black, R.W. \& Allen, A. (2007). "Becoming" a teacher. Teachers College Record, 109(9), 2107-2135.

Heafner, T., \& Plaisance, M. (2012). Shared viewing as an approach to transforming early field experiences. Contemporary Issues in Technology and Teacher Education, 12(4), 423437.

Huling, L. (1998). Early field experiences in teacher education. ERIC Clearinghouse on Teaching and Teacher Education. Washington, DC: ERIC Clearinghouse on Teaching and Teacher Education.,

Holland, D. Lachicotte, W., Skinner, D. \& Cain, C. (1998). Identity and agency in cultural 
worlds. Cambridge, MA: Harvard University Press.

Hollins, E.R. (2015). Rethinking field experiences in preservice teacher preparation. New York: Routledge.

Hollins, E. R. (2006). Transforming practice: Structured dialogue spurred educators at two underachieving schools to fuel their own professional growth. Educational Leadership (March), 48-52.

Hollins, E. R., McIntyre, L. R., DeBose, C., Hollins, K. S., \& Towner, A. (2004). Promoting a self-sustaining learning community: investigating an internal model for teacher development. International Journal of Qualitative Studies in Education, 17(2), 247-264.

Jackson, P. (1986). The practice of teaching. New York: Teachers College Press.

Joyce, B., Weil, M., \& Calhoun, E. (2014). Models of teaching (9th ed.). Upper Saddle River, NJ: Pearson.

Kaschak, J. C., \& Letwinsky, K. M. (2015). Service-learning and emergent communities of practice: A teacher education case study. The Clearing House: A Journal of Educational Strategies, Issues and Ideas, 88(5), 150-154.

Kenny, J. D. (2012). University-school partnerships: Pre-service and in-service teachers working together to teach primary science. Australian Journal of Teacher Education, 37(3).

Korthagen, F. (2004). In search of the essence of a good teacher: towards a more holistic approach in teacher education. Teaching and Teacher Education, 20(1), 77-97.

Labaree, D. (1997). Public goods, private goods: The American struggle over educational goals. American Educational Research Journal, 34(1), 39-81.

Lavadenz, M. \& Hollins, E.R. (2015). Urban schools as a context for learning teaching. In E. Hollins (Ed.), Rethinking field experiences in preservice teacher preparation. New York: Routledge.

Lincoln, Y. S., \& Guba, E. G. (1985). Naturalistic inquiry. Beverly Hills, CA: Sage.

Lotter, C., Yow, J. A., \& Peters, T. T. (2014). Building a community of practice around inquiry instruction through a professional development program. International Journal of Science and Mathematics Education, 12(1), 1-23.

Margolin, I. (2012). A coterminous collaborative learning model: Interconnectivity of leadership and learning. Brock Education Journal, 21(2), 70-87.

Marshall, C., \& Rossman, G. B. (2006). Designing qualitative research (4th ed.). Thousand Oaks, CA: Sage.

McQuirter Scott, R., Dortmans, D., Rath, C., Meeussen, N., \& Boin, J. (2015). Collaborative teacher inquiry into Ipad use in grade 3 classrooms: Mobilizing knowledge through a longterm school-university partnership. Brock Education Journal, 25(1), 73-90.

Merriam, S. B. (2009). Qualitative research: A guide to design and implementation. San Franscisco: Jossey-Bass.

Patton, M. Q. (2002). Qualitative research \& evaluation methods (3rd ed.). Thousand Oaks, CA: Sage.

Roland, K. (2010). Associate teacher perspectives of the triumvirate relationship in teacher education: The role of faculty advisors. Brock Education Journal, 19(2), 36-47.

Seidman, I. (2013). Interviewing as qualitative research: A guide for researchers in education and the social sciences $\left(4^{\text {th }}\right.$ ed.). New York: Teachers College Press.

Smith, K. \& Lev-Ari, L. (2005). The place of the practicum in pre-service teacher education: The voice of the students. Asia-Pacific Journal of Teacher Education, 33(3), 289-302.

Spalding, E., \& Wilson, A. H. (2006). Bowling together: Cultivating communities of practice in 
English and social studies teacher education. English Education, 38(2), 102-122.

Stairs, A. J. (2010). Becoming a professional educator in an urban school-university partnership: A case study analysis of preservice teacher learning. Teacher Education Quarterly, 37(3), 45-62.

Stake, R. (1995). The art of case study research. Thousand Oaks, CA: Sage Publications.

Strauss, A., \& Corbin, J. (1994). Grounded theory methodology: an overview. In N. K. Denzin \& Y. Lincoln (Eds.), Handbook of Qualitative Research (p. 273-285). London: Sage.

Trent, J., \& Lim, J. (2010). Teacher identity construction in school-university partnerships: Discourse and practice. Teaching and Teacher Education, 26(8), 1609-1618.

Warner, C.K. (2016). Contested definitions of excellent teaching: An analysis of the discourse of quality. Journal of Thought, 50(1), 20-36.

Wenger, E. (1998). Communities of practice. Learning, meaning, and identity. New York: Cambridge University Press.

Wenger, E. C., \& Snyder, W. M. (2000). Communities of practice: The organizational frontier. Harvard business review, 78(1), 139-146.

Wesley, P. W. (2003). Communities of practice: Connecting what we know. Exceptional Children, 69(3), 263-277.

White, S., \& Forgasz, R. (2016). The practicum: The place of experience? In J. Loughran $\&$ M. L. Hamilton (Eds.), International handbook of teacher education (pp. 231266). Singapore: Springer.

Zembylas, M. (2008). Interrogating 'teacher identity': Emotion, resistance and self formation. Educational Theory, 58(1), 107-127. 